\title{
RELIABILITAS KETENTUAN LAHAN FAKTOR PRODUKSI PERTANIAN UU RI NOMOR 5 TAHUN 1960 \\ TENTANG POKOK-POKOK AGRARIA DALAM ZAMAN KONTEMPORER
}

\author{
Manuasa Saragi*)
}

\begin{abstract}
Legislation No.5 Year 1960 about Agrarian promises to treat the land for fulfilling basic need and prosperity improvement of nationals, and also build nation (energy) power. The State of Indonesia has authority to do many such planning, using and determining the distribution of land for pursuing the greatest wealthy to individually and collectively, and building the nation and state power. Indonesia citizen can have a right to land determined by state regulation or derived from adat law. Factually, the land tends to accumulate in the hand of conglomerates, causes the chance of individually using the sufficient land to be hindered. In this research, the provisions about farming production factor was researched in legal normative method with question 'in what extend the provision of production factor of farming in legislation could be realized'. The result of the research, the provision itself not much implementing, one of causes is that the provision not so strong enough for selfcompleting its task. One policy to redistributing land in accordance with more fair manner should be done/considered immediately by government to heal the condition.
\end{abstract}

\section{Kata Kunci: Realibilitas, Ketentuan lahan produksi, Hak perorangan atas tanah; ketentuan faktor produksi pertanian; kemakmuran sebesar-besarnya.}

\section{Pendahuluan}

Satu janji Undang-undang Nomor 5 Tahun 1960 Undang-Undang tentang Peraturan Dasar PokokPokok Agraria (UUPA), memberi petani hak atas tanah sebagai sumber pemenuhan dan peningkatan penghidupan. Penggunaan lahan tersebut seyogianya dapat berkontribusi membentuk fondasi kelangsungan energi bangsa, mengantisipasi energi tak terbarukan segera akan habis. Keandalan kepastian ketentuan faktor produksi pertanian sangat penting, karena rakyat benteng terakhir energi. Gotong royong rakyat mesti diutamakan membangun jatidiri di tengah gravitasi global.

Perkembangan pesat perkebunan yang merambah hutan di Kalimantan, membuka perkebunan di Sulawesi hingga melakukan cara tidak sehat untuk izin usaha perkebunan, dan lebih luasnya terjarah hutan lindung Riau untuk pembukaan lahan perkebunan sawit, mengganggu keseimbangan berbagai varietas habitat pada hutan lama..

Terlihat dari Investasi perkebunan sawit tahun 2005-2010 milik Rakyat, BUMN, dan Swasta, Swasta secara kronologis memiliki seluas 2.567.068; 3.357.914; 3.408.416; 3.878.986; 3.885.470;
3.893.385 hektar. Petani memiliki hampir 5 hektar, klasifikasi 1988/1989, perkebunan besar minimal 25 hektar, lahan semakin terakumulasi ${ }^{1}$. Tahun 2009 milik swasta 3,8 juta hektar dimiliki oleh beberapa orang.

Luas tanah yang mungkin dibagi sebelum akumulasi terjadi sebagai berikut. Posisi 2015,Penduduk Indonesia 244.769.000 orang; angkatan kerja 117.000.000 orang...2 sebut sebagai '250 juta orang' membagi luas wilayah Indonesia (pengakuan archipelegic state dan Konvensi Hukum Laut Internasional 1982), kira-kira seluas $8.000 .000 . \mathrm{km}$ persegi, diperoleh hasil 32.000 meter persegi habitat dan penghidupan satu orang apakah petani/nelayan/dsb terlepas

\footnotetext{
* Dosen tidak tetap pada Pascasarjana Ilmu Hukum Universitas Mpu Tantular Jakarta

${ }^{1}$ Biro Hukum Dan Hubungan Masyarakat Badan Pertanahan Nasional, PENGADAAN TANAH Bagi Pembangunan Untuk Kepentingan Umum, Jakarta: Yayasan Bhumi Bhakti Adhiguna, 1994, h. 233.

${ }^{2}$ Buchari Bachter, MT Ketua Umum BPD HIPMI Sumatera Barat, Rancangan RPJMN 2015 - 2019 Dilihat Dari Sisi Dunia Usaha Dalam Menghadapi Komunitas Ekonomi ASEAN 2015: Penduduk Indonesia 244.769.000 orang; angkatan kerja 117.000.000 orang; pengangguran $\mathrm{kl} 7.700 .000$ orang;...; dari 244 juta orang 48,8 persen adalah anak muda.
} 
ahli atau kurang terdidik. Yang terkini, ada seorang memiliki 3.500 hektar perkebunan sawit. Meskipun pengguna cara tidak sehat sudah diadili(penyuapan), penumpukan tidak berhenti.Rencana perluasan perkebunan "perusahaan tertentu" di Kalimantan, menjadi 20.000.000. hektar pada $2019^{3}$.

Dalam acara Pertemuan Komisi IV DPR-Kelompok Tani Hutan-Lembaga Masyarakat Desa Hutan - Menteri KLH-Menteri Kehutanan, mengemuka: 245.000 hektar lahan direncanakan untuk pelestarian; 10 juta petani KTH di bawah garis kemiskinan. Menteri KLH: arti sustainable bahwa 20 tahun mendatang, yang baik sekarang dapat tetap baik kesananya ${ }^{4}$.

Makin terpinggirkannya petani untuk bertani dan membangun ketahanan energi nasional, mendesak perlu diatasi. Esensinya,faktor produksi tanahitu diperlukan untuk hal lebih mendasar. Undang-undang tidak menyebut eksplisit sebagai faktor produksi, akan tetapi subjek tertentu terikat (arahnya) untuk unsur memproduksi, apakah pertanian, atau layanan publik oleh pemerintahan.

Ungkapan gagasan tentang faktor produksi ${ }^{5}$ dalam UUPA: Pertama, ketentuan terkait langsung dalam faktor produksi pertanian:“...untuk mencapai sebesar-besar kemakmuran rakyat.... kebangsaan, dan Negara hukum Indonesia yang merdeka, berdaulat, adil dan makmur"; Yang punya hak atas tanah wajib mengerjakan sendiri...; untuk keperluan memperkembangkan produksi pertanian; dan... diatur luas maksimum dan/atau minimum tanah yang boleh dipunyai oleh satu keluarga..., Kedua, jejaring ketentuan yang menunjang, memberi batasan terhadap faktor produksi, di antaranya:Bagi kehidupan rakyat yang bercorak agraris, tanah relatif perlu dipertahankan. Apabila fosil habis karena tak terbarukan, jika kebutuhan pokok harus terus menerus mengimpor, pengelolaansumber daya alam (pertanian) patut dipertanyakan.

\section{Permasalahan}

1. Seberapa jauh ketentuan faktor produksi pertanian dalam Undang-undang tentang Peraturan Dasar Pokok-Pokok Agraria/UUPA dapat direalisasi di tengah perubahan zaman?

\footnotetext{
${ }^{3}$ KOMPAS TV, pkl.20.50 tanggal 17 Mei 2015, suatu informasi/ pemberitaan hasil wawancara pelindungan satwa, berubahnya fungsi hutan, banyak varietas fauna yang kehilangan habitatnya.

${ }^{4}$ TVRI, siaran tanggal 26 Mei 2015 Pukul 13 15, Acara Pertemuan Komisi IV DPR-Kelompok Tani Hutan (KTH)-Lembaga Masyarakat Desa Hutan (LMDH) - Menteri KLH-Menteri Kehutanan.
}

2. Apakah petani dapat memperoleh modal dasar lahan pertanian, baik melalui adat maupun hukum negara?

\section{Tujuan Penulisan}

1. Untuk mengetahui realisasi Undang-Undang RI No 5 tahun 1960 tentang Pokok-Pokok Agraria di tengah perubahan jaman.

2. Untuk mengetahui kesempatan petani memperoleh lahan pertanian berdasarkan Undang-Undang RI No 5 tahun 1960 tentang Pokok-Pokok Agraria.

\section{Metode Penelitian}

a Penelitian ini merupakan penelitian hukum normatif, yang memandang "penelitian hukum yang dilakukan dengan cara meneliti bahan pustaka atau data sekunder belaka, dapat dinamakan penelitian hukum normatif atau penelitian hukum kepustakaan"6. Data sekunder mencakup: a. Bahan Hukum Primer, yaitu bahan-bahan hukum yang mengikat b. Bahan Hukum Sekunder yang memberikan penjelasan mengenai bahan hukum primer, c. Bahan Hukum tertier"7.Penyusun memilih bahandi perpustakaan, fokus penelitian untuk menjawab "Apakah gagasan mengenai pengaturan hukum akan suatu perbuatan tertentu dilandasi oleh prinsip hukum, teori hukum atau filsafat hukum?", dalam identifikasi masalah.

b. Pendekatan konseptual,yaitu penelitian terhadap asas-asas hukum dilakukan terhadap kaidah-kaidah hukum yang merupakan patokan berperilaku atau bersikap tidak pantas....Penelitian terhadap asas-asas hukum merupakan suatu penelitian filosofis, oleh karena asas-asas hukum merupakan unsur ideal dari hukum ${ }^{9}$. Pendekatan ini untuk

\footnotetext{
${ }^{5}$ Pasal-pasal ketentuan pada UPA/UU 5/1960 yang mengandung makna Faktor Produksi, tidak eksplisit menyebut kata faktor produksi. Gagasan pada ketentuan bersangkutan yang merujuk (referent) terhadap fungsi/tugas perbuatan apakah inisiatif berusaha, pengaturan organik lanjutan yang hendak membangkitkan aktivitas kehidupan ekonomi mulai dari pemenuhan kebutuhan dasar dan peningkatan.

${ }^{6}$ Soerjono Soekanto dan Sri Mamudji, Penelitian Hukum Normatif -Suatu Tinjauan Singkat, Jakarta: PT.RajaGrafindo Persada, 2009, h..13-14.

${ }^{7}$ Soerjono Soekanto dan Sri Mamudji, Ibid, h.13.

${ }^{8}$ Johnny Ibrahim, Teori Dan Metode Penelitian Hukum Normatif, Malang: Bayumedia Publishing,2005, h.33.

${ }^{9}$ Soerjono Soekanto dan Mamudji, Penelitian Hukum Norma- tifSuatu Tinjauan Singkat, Jakarta: PT Raja Grafindo Persada, 1983, h..62
} 
memahami prinsip-prinsip ketentuan faktor produksi pertanian yangterdapat pada UUPA, dan bagaimana penerapannya terhadap pemerolehan tanah oleh petani untuk kebutuhan diri/keluarga dan ketahanan energi sehubungan dengan negara agraris.

\section{Bahan Penelitian}

a. Bahan hukum primer: Perjanjian Lama, sandaran keagamaan (Kitab Genesis); Pembukaan dan pasal-pasal UUD Negara Republik Indonesia Tahun 1945; Peraturan perundangan Tentang Pertanahan, peraturan perundangan lain yang terkait dengan penelitian.

b. Bahan hukum sekunder, yakni bahan-bahan yang erat kaitannya dengan bahan hukum primer, dan dapat membantu untuk proses analisis, yaitu Bukubuku ilmiah yang terkait, hasil penelitian terkait, makalah-makalah, jurnal-jurnal dan literatur yang terkait, doktrin hukum, pendapat ahli hukum.

c. Bahan hukum Tersier, yaitu kamus.

d. Bahan non hukum, yaitu bahan yang digunakan sebagai pelengkap bahan hukum yaitu: Bukubuku tentang Ekonomi tentang Faktor Produksi, Ciri Sumber Alam Jalannya Kemakmuran, Jurnal tentang Penanaman Modal.

\section{Tempat Pengambilan Bahan Penelitian}

Bahan hukum baik primer, sekunder maupun tersier serta bahan non hukum dalam penelitian ini diambil dari berbagai perpustakaan dan media massa cetak dan internet.

\section{Teknik Analisis Data}

Bahan hukum dan bahan non hukum yang diperoleh dalam penelitian ini dianalisis secara preskriptif dengan menggunakan metode deduktif yaitu data umum tentang konsepsi hukum baik berupa asas-asas hukum, postulat serta ajaranajaran untuk mengkaji keterandalan kaidah ketentuan faktor produksi UUPA merealisasi distribusi tanah pertanian keluarga/perorangan sesuai kebutuhan petani dalam negara agraris.

\footnotetext{
${ }^{10}$ Pusat Bahasa Departemen Pendidikan Nasional, Kamus Besar Bahasa Indonesia, edisi keempat, Jakarta: PT Gramedia Pustaka Utama, 2008, h. 387

${ }^{11} \mathrm{Ibid}$, h. 1103.
}

\section{Kerangka Konsepsional Dan Teoretis}

\section{Kerangka Konsep}

a. Reliabilitas ialah keandalan, dapat dipercaya menghasilkan hasil yang sama melalui berbagai pengujian.

b. Faktor berarti hal (keadaan, peristiwa) yang ikut menyebabkan (memengaruhi) terjadinya sesuatu ${ }^{10}$. Produksi ialah proses mengeluarkan hasil; penghasilan ${ }^{11}$.

Dari pengertian tersebut, faktor produksi merupakan elemen yang diperlukan dalam proses produksi. Pertanian berarti perihal bertani (mengusahakan tanah dengan tanam-menanam $)^{12}$.Pertambahan petani, kemajuan teknologi pertanian, menentukan realisasi reliabilitas dimaksud. Kontemporer berarti pada masa kini, dewasa ini. ${ }^{13}$

\section{Kerangka Teori}

a. Reliabilitas ketentuan faktor produksi (pertanian) akan teruji oleh kebutuhan pengguna, yang memerlukan proteksi, dan perjalanan hidup yang diterpa pelbagai peubah (hukum). Pola pikir ini, menganalogi pada productreliability dalam kendali mutu Juran ${ }^{14}$. Untuk mendapatkan hasil optimum baik produk barang maupun jasa, mesti dipenuhi meet the needs of the customers [petani], dan lainnya hingga penggunaan alat-alat perencanaan mutu $^{15}$.

b. Faktor produksi sebagai fundamental ekonomi antara lain tanah,skill, teknologi.Samuelson dan Nordhaus mengatakan: Jika anda tidak berencana menjalankan perusahaan anda dari sebuah balon udara, tanah merupakan faktor produksi yang penting untuk bisnis apapun. Ciri yang tidak biasa dari tanah adalah bahwa kuantitasnya tetap dan sangat tidak responsif terhadap harga ${ }^{16}$

Penyediaan ketentuan faktor tersebutdalam UUPA diteliti spirit dan tujuannya.

\footnotetext{
${ }^{12}$ Ibid, h. 1400.

${ }^{13} \mathrm{Ibid}$, h. 729.

${ }^{14}$ J.M.Juran, Juran on Quality by Design - The New Steps for Planning Quality into Goods and Services, The Free Press a Division of Simon \& Schuster Inc. 1230 Avenue of Americas,1992, h.4, 190, 192, 345.

${ }^{15}$ Juran, Ibid, h. 169-170.

${ }^{16}$ Paul A. Samuelson dan William D. Nordhaus, (edisi terjemahan), Ilmu Mikro Ekonomi, P.T Media,Global Edukasi, 2003, h.313.
} 
c. Prinsip hukum ketentuan faktor produksi pertanian

1) "Asas hukum merupakan pokok pikiran yang bersifat umum yang menjadi latar belakang dari peraturan hukum yang konkret (hukum positif)" 17 . Asas disini sama dengan prinsip hukum. Pengundangan UUPA, selain untuk kepastian, dimaksudkan membentuk ekspektasi (negara, rakyat, pelaku usaha, pemilik ulayat).

2) Membentuk kehidupan ekonomi, dan lingkungan hidup menjadi lebih baik, bagi diri/ keluarga, dan ketahanan energi nasional. Menurut UUD 1945: pemerintah memajukan kesejahteraan umum, perekonomian berbasis kekeluargaan. Pasal 33 ayat (4) mempertegas dukungan terhadap asas kekeluargaan, dengan efisiensi berkeadilan, berkelanjutan. Asas bersangkutan telah tertanam (embedded) dalam jiwa UUD. Undang Undang Nomor 12 Tahun 2011: "materi undang-undang semestinya mengandung asas-asas pengayoman, kemanusian, kekeluargaan, kenusantaraan, kebhineka tunggal ikaan, keadilan, kesamaan kedudukan dalam hukum dan pemerintahan, ketertiban dan kepastian hukum, dan/atau keseimbangan, keserasian, dan keselarasan".

Dalam Undang-Undang No.32 Tahun 2009 , di antaranya asas tanggung jawab negara; dalam Undang-Undang Nomor 41 Tahun 2009, asas: a. manfaat, b. keberlanjutan dan konsisten, c. Keterpaduan, d. keterbukaan dan akuntabilitas. Dalam UU Nomor 4 Tahun 2009 tentang Pertambangan Mineral Dan Batu Bara, untuk perhatian mengenai reklamasi. Undang-undang sesudah UUPA berkepedulian serupa dengan yang semestinya dipentingkan UUPA berkenaan dengan faktor produksi. UUPA agak unik, berkarakter publik dan privat(perjanjian), serta layanan administrasi (good governance).

Dalam perbedaan filsafat dan ideal politik pada pendogmatikan hukum positif (berprimasi individual, komunal) dapat membawa antinomis pada ketentuan faktor produksi. Ketentuan faktor tersebut bukan sekedar untuk ekonomi sub sistensi atau nafkah. Dalam

\footnotetext{
${ }^{17}$ Sudikno Mertokusuma, Mengenal Hukum, Liberty, Yogyakarta, 1985, h.32., sebagaimana dikutip dalam Bambang Sutiyoso dan Sri Hastuti Puspitasari, Aspek-Aspek Perkembangan Kekuasaan Kehakiman, Yogyakarta: UII Press, 2005, h.65-66.
}

perkembangan keamanan, ikhwal urusan telah bergeser pada kehidupan manusia sehari-hari dengan bentangan kebutuhan dan pekembangannya. ${ }^{18}$ Bercermin pada perkembangan konstitusional demikian, bahwa ketahanan negara mesti dibentuk juga terefleksi dari ketahanan rakyatnya yang berkelanjutan secara permanen.

3) Sudargo Gautama, menguraikan prinsip-prinsip hukum UUPA ${ }^{19}$ : a) Pencabutan hukum lama, membuat pembaruan aturan dan prinsip hak pertanahan;b) Konsep satu kewarganegaraan Indonesia; c) Unifikasi peraturan hukum perundang-undangan; d) Pedoman dari Menteri Agraria tentang pertanahan.

d. Negara Hukum Kesejahteraan

Negara hukum diungkapkan dalam pembukaan dan pasal UUD Negara Republik Indonesia Tahun 1945, dilanjutkan dengan hak dasar warga negara di bidang ekonomi, dan kesejahteraan umum. Frederich Julius Stahl mengemukakan bahwa negara kesejahteraan tidak sekedar memberi jaminan juridis hak warga negara, melainkan proaktif mengarahkan tercapainya tujuan kesejahteraan umum ${ }^{20}$.

Pandangan Ihering: Milik tidak semata-mata buat pemilik, melainkan juga untuk masyarakat. Hukum mesti mencoba mempertemukan kepentingan-kepentingan dari dua. Dia membenarkan pengambilalihan (expropriation) atau pembatasan hukum atas pelaksanaan hak-hak milik individu, penyelarasan kepentingan-kepentingan masyarakat dengan pemilik. Baginya tiga kelompok kepentingan yang utama: Individual, state and society $^{21}$. Ide ini selaras dengan keperluan pengendalian lahan yang telanjur terakumulasi pada segelintir orang.

Dalam kajian Renner tentang Property dalam masyarakat kapitalis, dikemukakan: lembagalembaga hukum berdiri di tengah antara proses

\footnotetext{
${ }^{18}$ Lihat, Krisna Harahap, Konstitusi Republik Indonesia-Sejak Proklamasi hingga Reformasi, Bandung: Grafitri Budi Utami, 2004, h.265.

${ }^{19}$ Lihat, Sudargo Gautama, Indonesian Business Law, Bandung: PT.Citra Aditya Bakti, 1995, h.143-174.

${ }^{20}$ Frederich Julius Stahl, sebagaimana dikutip dalam Krisna Harahap, Konstitusi Republik Indonesia-Sejak Proklamasi hingga Reformasi, Bandung: Gafitri Budi Utami, 2004.h.56

${ }^{21}$ W.Friedmann, Legal Theory, Columbia University Press New York, Stevens \& Sons Limited, London, 1967, h.324.
} 
pembuatan hukum dan fungsi sosial dari hukum. Masyarakat menghasilkan cara hidup tertentu dalam suatu proses perubahan permanen dan evolusi.... Akhirnya, ketegangan antara bentuk dan fungsi menjadi sangat besar bahwa masyarakat membentuk hukum baru, dan proses yang sama mulai kembali. kepe-Milik-an awalnya, adalah dalam hukum berarti kekuasaan absolut melepas benda/barang... tempat bekerja dan produksi, tempat konsumsi, pasar dan keluarga. Kemudian Marx, mengartikulasikan... kapitalis telah menjadi satu komandan industrial ${ }^{22}$ (terjemahkan penyusun).

e. Akomodasi keseimbangan kepentingan

1) Menurut Radbruch, teori (filsafat) berfungsi mengklarifikasi nilai-nilai hukum dan postulat-postulatnya hingga fundamental filsafat terdalam ${ }^{23}$.Obsesi umum, kualitas kesejahteraan atau kemakmuran yang berbasis Pancasila bukan lipservice. Oleh karena itu, cara tertentu dipertanyakan kecocokannya untuk pencapaian dimaksud.

Hal sepenting ekonomi, harkat martabat yang tercecer, perlu ditelusursecara falsafat, sebab "berfilsafat berarti berendah hati atas keterbatasan diri. sedangkan juga Filsafat sebagai cara berpikir radikal dan menyeluruh. termasuk berani berterus terang atas capaian" 24 .

2) R.M.Dworkin dalam Is Law A System of Rules, mengingatkan: a. Bahwa seperangkat aturan pada masyarakat, disasarkan untuk tindakan mana yang dihukum atau dipaksa oleh kekuasaan publik; b. Kekurangjelasan undang-undang diatasi dengan diskresi pejabat... c. berkewajiban hukum, orang bersikap mesti/ urung melakukan sesuatu .... uji fundamental atas silsilah aturan mesti mendapatkan perhitungan sebagai suatu aturan hukum ${ }^{25}$

\footnotetext{
${ }^{22}$ Ibid h.368-369.

${ }^{23}$ Ibid. h. 4 .

${ }^{24}$ Lihat, Kinayati Djoyosuroto, Filsafat Bahasa, Yogyakarta: Pustaka Book Publisher, cet.kedua (edisi revisi), 2007, h.21

${ }^{25}$ R.M.Dworkin, The Philosophy of Law, Oxford University Press, 1977, h. 38-39.
}

\section{Hasil Penelitian Dan Pembahasan}

\section{Isu Hukum: Seberapa Jauh Ketentuan Faktor Produksi Pertanian DalamUndang- Undang Tentang Peraturan Dasar Pokok- Pokok Agraria/UUPA Dapat Direalisasi Di Tengah Perubahan Zaman?}

\section{a. Data Lahan Yang Dapat Didistribusi}

Luas wilayah Indonesia sekitar $2.000 .000 \mathrm{~km}^{2}{ }^{26}$ Deklarasi Djuanda 1957 diikuti Perpu 4/1960 wilayah Indonesia menjadi sekitar $5.000 .000 \mathrm{~km}^{2}$, berdasar Konvensi Laut, 1982 (UNCLOS) di mana Indonesia diakui sebagai negara kepulauan, klaim Zona Ekonomi Eksklusif 200 mil laut, wilayah menjadi $8.000 .000 \mathrm{~km}$ persegi. Perubahan menjadi 5 juta dan 8 juta $\mathrm{km}^{2}$, Cuma sedikitp engaruhnya bagi petani. Sedikit kompetitor beralih mengusahakan lahan bidang kelautan, tambang off shore, perikanan. Dengan demikian, lahan yang potensial bagi calon petani, sekitar 2.000.000. $\mathrm{km}^{2}$ : jumlah populasi petani. Berdasarkan equal right, atau equality ${ }^{27}$ semua penduduk (WN) Indonesia sebagai petani, maka (244.769.000. orang, 2015) ${ }^{28}$ membagi lahan $2.000 .000 . \mathrm{km}^{2}$ (perairan dalam, tempat unggas, harimau, ikan dan hutan lindung), hasilnya kira-kira $8.196,72 \mathrm{~m}^{2}$ per orang. Jika pembaginya angkatan kerja 117 juta orang, maka hasilnya 17.094,017 $\mathrm{m}^{2}$. Potensi itu tidak banyak bergeser, jika mayoritas masyarakat berprofesi agraris. Saya Kuliah Kerja Nyata tahun $1979^{29}$, melihat distribusi lahan bagi petani di daerah Transmigrasi 2 (dua) hektare per kepala keluarga, dikelola secara konvensional. Dengan populasi sekitar 1.100 keluarga, areal transmigrasi tersebut menggunakan sekitar 3.000.

\footnotetext{
${ }^{26}$ Lihat, Majelis Permusyawaratan Rakyat, Panduan Pemasyarakatan Undang-Undang Dasar Negara Republik Indonesia Tahun 1945, Sekretariat Jenderal MPR RI: 2008, h.108-109; lihat juga, Arif Djohan Tunggal, Hukum Laut, Jakarta :Harvarindo, 2008, h.8.

${ }^{27}$ Lihat, proposal Jeremy Bentham Theory of Legislation antara lain menggambarkan, dalam suatu negeri/bangsa yang makmur secara agrikultur, manufaktur dan perdagangan terdapat suatu kemajuan yang berkesinambungan kearah persamaan, dinarasikanW.Friedmann, Legal Theory, London: pen. Stevens \& Son Limited, London, 1967, h.318. Negeri yang belum siap bersaing bebas (Indonesia), teori ini perlu diimbangi dengan policy pemerintah untuk keberpihakan.

${ }^{28}$ Dari data Ir. Buchari Bachter, MT Ketua Umum BPD HIPMI Sumatera Barat, Strategi Pelaku Bisnis Menghadapi Komunitas ASEAN 2015 (pdf), catatan kaki 2. di atas.

${ }^{29}$ Kuliah Kerja Nyata (KKN) mahasiswa Universitas Sumatera Utara, pada Oktober s/d Desember Tahun 1979 di lokasi Transmigrasi Desa/Kelurahan Aek Naetek, Kec. Kuala Hulu, Kab. Rantau Prapat, Provinsi Sumatera Utara.
} 
hektar lahan termasuk sarana/prasarana fisik lainnya bagi kelurahan rintisan. Disandingkan dengan luasan potensial 0,8 hektar per orang hampir sama dengan 2 hektar per keluarga/suami dan isteri.

Melalui pembagian sama rata, berkesan menjadi petani tidak menjanjikan perbaikan. Untunglah, tidak semua angkatan kerja menjadi petani, dan jumlahnya belum fixed seperberapa 117 juta orang/data 2015. Petani yang membutuhkan kemauan dan kemampuan adalah lebih termotivasi suatu dinamika. Untuk ituperlu, seminimum apa luasan yang pasti didapatkan petani untuk mengurus dirinya dan mempertahankan energi nasional. Sebelum pada dua atau sampai lima hektar, telah tergambar ada rasio yang lebih patut(reasonableness) untuk membaca kontrak negara bersama pemberi karunia, memperlakukan rakyatnya.

Menurut Juran: untuk mendapatkan hasil optimum baik produk barang maupun jasa, mesti dipenuhi antara lain meet the needs of the customers, dan lainnya hingga penggunaan alat-alat perencanaan mutu $^{30}$. Petani sebagai pengguna tatanan yang diproduk oleh kualifikasi tertentu. Transformasi konsep optimum, mesti dijembatani tata kelola (governance) yang baik, sehingga berapa minimum diperlukan bagi petani (customers) terjawab; luas yang dapat digunakan (available), dan apa pilihan teknologipertanian bersambut. Cara kontemporer mengintensifkan pekarangan hanya kurang dari 1 hektar di sekeliling rumah, banyak yang berhasil (bertani anggrek, buah naga, luas tak mutlak), sebaliknya merambah hutan mengakibatkan kerusakan yang lebih besar ketimbang hasil yang tak seberapa. Luasan bukan angka statis, disesuaikan terhadap manfaatnya, dan pilihan seperti ekstensifikasi atau intensifikasi bersifat kondisional juga disesuaikan dengan perhitungan ahlinya.

Data di atas dapat dibandingkandengan pemilikan berikut, memperlihatkan taksiran apakah makin baik bagi petani, atau harapannya tertinggalkan jauh-jauh.

Ribuan cerita dari tabel Luas Areal Perkebunan Kelapa Sawit, mulai success story (pertumbuhan), dan perbuatan fatal dibalik pembuatannya.'Tidak harmoninya UUPA ditindaklanjuti', seperti hasil Kajian Komisi Hukum Nasional pada 2008 Tinjauan Terhadap UU No 5 Tahun 1960, menyimpulkan antara lain: (a) Bahwa terdapat ketidaksinkronan antara berbagai peraturan yang me-ngatur tentang tanah di bumi Indonesia ini. menyebabkan kebijakan agraria di Indonesia "berwajah sektoral"32.

Uraian berikut, UUPAuntuk pemenuhan kebutuhan keluarga dan menunjang energi terbarukan esok. Sejak krisis minyak 1973, pakar energi sudah serius terhadap perencanaan energi karena fosil segera habis. Untuk ukuran nasional, kita berbicara yang dapat diekstraksi, dan rencana bersama pembentukan ketahanan energi melibatkan partisipasi aktif petani sekaligus memenuhi keutamaan kesejahteraan sosial ${ }^{33}$. UUPA bermaksud mengondisi prosespenyejahteraan

Luas Areal Perkebunan Kelapa Sawit ${ }^{31}$

Berdasarkan Kepemililikan Tahun 2005-2010

Luas Lahan ( $\mathrm{Ha})$

\begin{tabular}{|c|c|c|c|c|}
\hline Tahun & Rakyat & BUMN & Swasta & Total \\
\hline 2005 & 2.356 .895 & 529.854 & 2.567 .068 & 5.453 .817 \\
\hline 2006 & 2.459 .572 & 687.428 & 3.357 .914 & 6.594 .914 \\
\hline 2007 & 2.752 .172 & 606.248 & 3.408 .416 & 6.766 .836 \\
\hline 2008 & 2.881 .898 & 602.963 & 3.878 .986 & 7.363 .847 \\
\hline 2009 & 3.013 .973 & 608.580 & 3.885 .470 & 7.508 .023 \\
\hline 2010 & 3.314 .663 & 616.575 & 3.893 .385 & 7.824 .623 \\
\hline
\end{tabular}

\footnotetext{
${ }^{30}$ J.M.Juran, Juran on Quality by Design - The New Steps for Planning Quality into Goods and Services, pen. The Free Press a Division of Simon \& Schuster Inc. 1230 Avenue of Americas,1992, h. 170 .

${ }^{31}$ Dicuplik dari tabel Luas Areal Perkebunan Kelapa Sawit Berdasarkan Kepemilikan Tahun 2005-2010, sumber: Kementerian Pertanian diolah oleh CDMI.
}

\footnotetext{
32 www.komisihukum.go.id//hukum agraria-1960-masyarakat-hukum-adat-perlukah-reformasi hukum agraria, diakses, tanggal 29 Mei 2015, pukul 15.20.

${ }^{33}$ Lihat, Maxime Kleinpeter, Energy Planning And Policy, Unesco, 1995, h.34-35
} 
semua baik keluarga/perorangan maupun kolektif, dan negara tidak loyo. Pe(r)tani(an) keluarga mendekati 5 hektar. Gap sangat besar terjadi untuk memeroleh akses penyejahteraan. Tanpa kebijakan berpihakuntuk rencana terarah, kecenderungan ini jelas berbahaya,ada kultur negatif memandang kepemilikan yang tak terkendali sebagai rezeki dari yang less responsible.

Tahun 2009, milik rakyat: 3.013.973, itu setidaknya digunakan 602.794 kepala keluarga. Tahun yang sama, lahan swasta 3.885.470 hektar dimiliki oleh beberapa orang ${ }^{34}$, cenderung meminggirkan the greatest number unsur bangsa.

Orang menjadi kaya sah saja, namun cara curang mencari untung harus dicegah. Hubungan karyawan dengan pemilik tidak sekedar posisi modal dan untung rugi, hukum yang memberikan nilai martabat manusia akanbanyak absen dalam transisi yang seolah-olah diwakili kerajaan kapitalis dengan rambu yang tercipta secara kontraktual. Dapat disimpul, bahwa pembagian yang dialokasi pemerintah terhadap petani belum demikian sinifikan menurut janji UUPA seperti redistribusi.

\section{b. Norma faktor produksi}

1) Pasal 2 Ayat (3): “...untuk mencapai sebesarbesar kemakmuran rakyat. kebangsaan, dan Negara hukum Indonesia yang merdeka, berdaulat, adil dan makmur". Kehidupan negara yang rakyatnya mendapat kebahagiaan jasmani dan rohani akibat terpenuhi kebutuhannya, seperti itulah 'makmur' menurut kamus. Karenanya, pemakmuran paling pantas, membuat negara kuat dan rakyat kuat.

Prinsip hukum awalnya 'pengakhiran keterjajahan dan membina identitas'. Di desa/kampung, negara, dan dalam hubungan internasional tercipta jaminan keberlangsungan yang baik-baik ${ }^{35}$. Asas yang solid didukung kemauan politik. Notonagoro merekomendasi: jangan membayangkan semua orang menguasai lahan, tanah terbatas, perlu modernisasi, dan gravitasi politik internasional. , mesti direspons dengan sikap efisiensi mengelola bumi. angkasa ${ }^{36}$.

\footnotetext{
${ }^{34}$ Dicuplik dari tabel Luas Areal Perkebunan Kelapa Sawit Berdasarkan Kepemilikan Tahun 2005-2010, sumber: Kementerian Pertanian diolah oleh CDMI.

${ }^{35}$ TVRI, siaran tanggal 26 Mei 2015 Pukul 13 15, Acara Pertemuan Komisi IV DPR-Kelompok Tani Hutan (KTH)-Lembaga Masyarakat Desa Hutan (LMDH) - Menteri KLH-Menteri Kehutanan.

${ }^{36}$ Notonagoro, Politik Hukum Dan Pembangunan Agraria Di Indonesia, Jakarta: PT.Bina Aksara, 1984, h. 60-61.
}

Garis Besar Haluan Negara 1973 hingga pembangunan jangka panjang yang pertama sudah kuat mengarahkan trilogi pembangunan yakni stabilitas, pertumbuhan dan pemerataan, yang amat tertinggal justru pemerataan. Apabila pengakumulasian pertanian/perkebunan terus dibiarkan, maka tidak ubahnya seperti VOC jauh sebelum GBHN itu. Di negeri maju kaum buruh sudah pada pemilikan/share bagian perusahaan di mana mereka sebagai karyawan, sebaliknya di Indonesia masih berjuang hidup layak, seperti yang dikemukakan Franz Magnis Suseno, solidaritas bangsa Indonesia sekarang terancam: oleh terpecahnya bangsa ke dalam kelompok yang maju dan hanya pas-pasan dapat mempertahankan diri,... bahaya tergusur, penghidupannya dimatikan, diusir dari tanah yang mereka garap;..., yang diilustrasi tersebut pada empat dekade yang lalu, pada belakangan ini kondisi yang memprihatinkan itu makin mengen$\mathrm{tal}^{37}$. WNI berhak memiliki lahan, dan perusahaan diharapkan tidak menjadi pemeras. Akan tetapi selama karyawan hanya sebagai buruh, belum berkelayakan sebagai pemilik. Apabila lahan menjadi perkebunan besar, rakyat terhalang untuk turut menyejahterakan dirinya.Sejak merdeka, semangat bernegara hukum, yang memuara pada hak-hak asasi sudah kuat. Persaingan yang sehat merupakan upaya optimalisasi pada sikap taat hukum. Yang terjadi pada agraria dalam objek kajian, tidak terlepas dari kehidupan kenegaraan Indonesia.

\section{c. Pengwujudan sila dengan pengayoman, pre- diktabilitas $^{38}$}

Pengakuan manusia sebagai ciptaan Tuhan; Mempunyai peri kemanusiaan yang adil; Rasa Kebangsaan; musyawarah, dan keadilan bagi seluruh rakyat Indonesia. Nilai filosofis ini harus diasah, oleh masyarakat Indonesia. Penyejahteraan harus berjiwakan rasa kekeluargaan. Pertimbangan UUPA menghadirkan spirit tersebut: '...sebagai karunia Tuhan Yang Maha Esa mempunyai fungsi yang adil dan makmur', Berpendapat, butir c. Bahwa hukum agraria nasional itu harus mewujudkan penjelmaan daripada [Pancasila], sebagai azas kerohanian Negara dan cita-cita Bangsa seperti yang tercantum di dalam Pembukaan UUD,

\footnotetext{
${ }^{37}$ Lihat, Franz Magnis Suseno, Filsafat Kebudayaan, (diedit Swandi S. Brata), Jakarta: pen.PT Gramedia Pustaka Utama 1992 , h. 248 .

${ }^{38}$ Lihat, B.Arief Sidaharta, Pradikamenta Indonesiana, h.22-31. Poin strategis yang sangat penting mengeksplisitkan Pancasila $\mathrm{d}$ antaranya berkenaan dengan prediktabilitas dan pengayoman.
} 
...dan ... seluruh bumi ... sebagai karunia Tuhan Yang Maha Esa ... merupakan kekayaan nasional'.

Prinsip Hukum Barat mendorong kemajuan, dan Prinsip Hukum Adat meng-konservasi local wisdom, kepribadian, unitas spiritualitas dan fisikal. Dalam hal terjadi antinomi, mungkin juga sukar ada yang rela mengalah, karenanya harus dimoderasi (penyesuaian). Menggeser hak adat (tanah) sesuai dengan UUPA, berimplikasi bahwa harus ada rencana besar nasional, arah politik hukum, rencana strategis yang lebih solid dapat mengakomoder semua kepentingan. Pasal 5 UUPA(1960) menyebut: Hukum agraria yang berlaku ... ialah hukum adat, sepanjang tidak bertentangan dengan kepentingan nasional dan negara, ..., dengan sosialisme Indonesia serta... peraturan perundangan lainnya, segala sesuatu dengan mengindahkan unsur-unsur yang bersandar pada hukum agama.

\section{d. Pasal 10 ayat (1) Yang punya hak atas tanah wajib mengerjakan sendiri}

Asas "keserasian, keselarasan, dan keseimbangan" dalam perlindungan lahan pertanian pangan berkelanjutan yang harus mencerminkan keserasian, keselarasan, dan keseimbangan antara kepentingan individu dan masyarakat, lingkungan, dan kepentingan bangsa dan negara serta kemampuan maksimum daerah. Asas "tanggung jawab negara" adalah perlindungan lahan pertanian pangan berkelanjutan yang dimiliki negara.

Tindaklanjuti dengan pelbagai peraturan perundangan (hingga Peraturan Menteri), yang terutama berkenaan dengan pengepasan hak-hak tanah dengan format UUPA, mengesankan sangat jauh dari memadai realisasinya. Daerah yang kental dengan hak-hak komunal adat akan dibanguni suatu infrastruktur jalan menjadi sarana pemerintah, secara umum sangat sukar ditepati perencanaannya terkait pembebasan tanah. Selain perlunya penyelesaian satu dua kasus dengan musyawarah, terpentingbagaimana merealokasi hak komunal yang agak beku menjadi cair dengan subyek tertentu dapat diajak berdialog sebagai pemilik hak menyambut upaya kemajuan yang lebih rasional.

\section{e. Pasal 14 ayat (1) d. Untuk memperkembang- kan produksi pertanian}

1) Asas tanggung jawab negara, mengkondisikan agar rakyat dapat memperoleh kebutuhan dasar (basic need) dan perkembangan dengan baik terpadu dengan konsep ketahanan energi. Negara mencegah pencemaran lingkungan dan kerusakan lingkungan hidup.

2) Untuk keperluan memperkembangkan produksi pertanian, peternakan dan perikanan serta sejalan dengan itu, sebagai bagian dari rencana umum yang akan dibuat Pemerintah. Pertanyaannya, berapa luas lahan minimum pertanian tuntutan kebutuhan faktor produksi. Fungsi kebutuhan hidup layak dan tulang punggung energi nasional untuk jangka panjang, bersifat dinamik. Fakta-fakta yang akan dipertimbangkan seperti pilihan produksi yang bersifat masif (mungkin juga seperti sawit, karet, tanaman keras) yang diminta pasar. Berapa lahan tersedia untuk cadangan produksi pertanian seperti yang dipilih; konteks keselamatan keragaman hayati, data seperti ini hasil koordinasi antar institusi pemerintah dan masyarakat keseluruhan.

\section{f. Pasal 17 (1) Diatur luas maksimum dan/atau} minimum yang boleh dipunyai oleh satu keluarga

1) Pertanian sebagai syarat bagi pemenuhan kebutuhan dan energi nasional perlu dijelaskan secara terbuka, akuntabel. Pemihakan, membuat faktor produksi pertanian menjadi sentral. Pencegahan pemilikan yang melebihi (Pasal 7 UUPA), menyerahkan tanah berlebih bagi petani yang membutuhkan, dan perasionalan maslahat terbesar, merupakan indikator kunci arah capaian. Reliabilitas itu, sebagai volition ${ }^{39}$ dideterminasi oleh swatenaga UUPA atau ketentuan lainnya, terkait faktor X Petani (jumlah, kesediaan), Y (perkembangan teknologi), dan faktor $\mathrm{Z}$ (pilihan bersama) cara mempertahankan energi. Ini terpenting karena aturan harus harmoni dan dapat bersinergi pada tujuan.

2) Apakah ada tanah adat yang tersedia bagi warganya Setara Dengan Kebutuhan Minimal Keluarga Petani melebihi perekonomian subsistensi?

\footnotetext{
${ }^{39}$ Eryan A Garner (editor in chief), Black's Law Dictionary, eight edition, 2009, h.1605, memberi arti Volition: The ability to make a choice or determining something. Dalam hal kaedah yang menginduk pada aturan yang lebih tinggi, kedudukannya menindaklanjuti keinginan induk. Hal norma bebas lepas, norma itu sebagai norma dasar. UUPA, pertama menginduk pada UUD, kedua, ditindaklanjuti pada berbagai kewenangan, hingga jika koordinasi melemah banyak peluang divergensi. Sehingga tepat/ tidak terimplementasi setidaknya dapat bersumber dari dirinya sendiri/UUPA, dan kuasi lesislatif (diskresi eksekutif).
} 
Yurisprudensi Mahkamah Agung, tanggal 11 Juni 1958 No.279 K/Sip/1957, hal Perampasan. Dalam duduk perkara: 'bahkan tergugat telah dihukum olehKerapatan Balai Urung Panai [kerapatan adat], tiap kali mendapat hukuman denda, tetapi hal itu tidak dihiraukan. Intinya, persawahan yang subsistensi saja sudah tidak solid teralokasi dari putusan pengetua adat. Apakah kasus tersebut sebagai penanda kemajuan atau kemunduran legitimasi kerapatan adat, tampaknya pengambil putusan adat tidak sampai turut merencanakan kehidupan sosial ekonomi anggota masyarakat yang telah bersintuhan dengan modernitas. Putusan ini dua tahun sebelum pengundangan UUPA, para pihak mengajukan gugatan ke Pengadilan Negeri, mengindikasi bahwa pokok-pokok penting penghidupannya yang dikelola pribadi tidak bergantung pada putusan adat.

\section{f. Pengaruh Milik dalam masyarakat kapitalis}

Kemiripan teori Renner dalam kajian tentang property dalam masyarakat kapitalis dengan akumulasi lahan pertanian/perkebunan, banyak terlihat pada pemodal sangat berkuasa, karyawan nyaris tidak mempunyai bargaining position untuk menentukan jalannya pemakmuran yang merata. Bagaimana kita melihat kemiripan, pemilik(an) Perkebunan Besarbesaran yang makin merambah saja belakangan ini Sumatera, Kalimantan, mesti tidak melongo. Agar tidak seperti di Sri Lanka, 'the society has become evil (plantation worker in Sri Lanka)' dan,. But the early promises of leaders and officials were not fulfilled, and people soon felt that development schemes and other government initiatives failed to benefited the vast majority. Rakyat kecewa terhadap lakon pemerintahny ${ }^{41}$.

Kaidahnya, pertanian dimiliki pribadi atau badan hukum dikerjakan sendiri, menghindarkan pemerasan, ini sejajar dengan 'semua warga negara Indonesia berkesempatan memiliki lahan', dan katup pengamannya pada pemerintah. Luas berlebihan akan diambil alih dibagikan pada rakyat. Pembagian lahan dimungkinkan jika ada maneuver kebijakan terarah dari pemerintah, karena lahan untuk pertanian sudah nyaris habis oleh konglomerasi perkebunan. Negara

\footnotetext{
${ }^{40} \mathrm{R}$.Subekti, Hukum Adat Indonesia Dalam Yurisprudensi Mahkamah Agung, PT.Alumni Bandung, cetakan kelima 2006, h 103.

${ }^{41}$ Barry Knight, et al, Reviving Democracy - Citizen at the Heart of Governance, London: Earthscan Publication Limited, 2002, h.90 dan h.115.
}

harus mengembangkan payungnya, seperti yang dikemukakan Bachtiar Effendi, melalui hak menguasai negara, negara berhak di sektor agraria untuk selalu campur tangan dengan pengertian bahwa setiap pemegang hak atas tanah tidak berarti bahwa akan terlepas dari hak menguasai negara tersebut ${ }^{42}$.

\section{g. Filsafat Hukum Melihat Kaidah Penggunaan Lahan Pertanian}

1) The idealistic character of BAL (Basic Agrarian Law)..., the rich Indonesian land, water and air are 'blessing of God'43. Mencetak keidealisan menjadi realitas, mesti melalui usaha yang sungguhsungguh. Ia/kaidah sebagai alat dan wadah ikhtiar mewujudkan cita hukum. Namun tak dapat dilupakan juga mesti sebagai objek terevaluasi bagi pengwujudannya. Yang dalam jangkauan mesti diimplementasikan, misalnya batasan kuantitatif luas yang diperkenankan, maupun yang dilarang dikuasai. Ditumbuhkan kepercayaan, bahwa turunan regulasi membawa proses penyejahteraan dan pemakmuran. Tentulah harus diikuti komitmen dan integritas penindaklanjut (legislator, dan birokrat terkait).

Alam pikiran Pancasila menyediakan ruang untuk keseimbangan, masalahnya lahan terakumulasi merupakan kondisi yang kebablasan ${ }^{44}$, mungkin sudah harus dikelola dengan seni $\left(a r t^{45}\right)$ tersendiri. Pemerintah dituntut lebih berani membeli lahan para kapitalis untuk dibagikan ke pada petani. Sebagai prosedur yang efisien dari keadilan hukum alam, pemikiran Fuller mendeduksi suatu 'inner morality' of law from the very nature of legal system, dari 8 butir, 2 diantaranya intelligibility and clarity dan congruence between official action and declared rule ${ }^{46}$. Pemenuhan syarat dan kejernihan serta kesesuaian lakon resmi dengan aturan yang dikumandangkan masih sangat-sangat diperlukan untuk menyentuh pencapaian ideal janji UUPA.

\footnotetext{
${ }^{42}$ Bachtiar Effendi, Kumpulan Tulisan tentang Hukum Tanah,. Alumni, Bandung, 1982, h.2-3.

${ }^{43}$ Sudargo Gautama, Indonesian Business Law, Bandung: Citra Adtya Bakti, 1995, h.170

${ }^{44}$ Pusat Bahasa Departemen Pendidikan Nasional, Kamus Besar Bahasa Indonesia, edisi keempat, Jakarta : PT Gramedia Pustaka Utama, Jakarta, 2008, h. 109. "Kebablasan berarti terlewat dari batas atau tujuan yang sudah ditentukan; keterlaluan."

${ }^{45}$ Lihat, George Whitecross Paton, A Text Book of Jurisprudence, Oxford at Clarendon Press, 1946, h.149, menyoal seberapa jauh hakim dapat mengembangkan hukum menurut uraian ilmiah Apakah sekedar seni, katanya.

${ }^{46}$ Fuller, The Morality of Law, h.6 dst, sebagaimana dikutip dalam W.Friedmann, Legal Theory, 1967, h.18.
} 
Ada keraguan, bahwa jangan-jangan tidak diniatkan untuk bisa seoptimum mungkin mencapai ekspektasi dalam UUPA bersangkutan. Kajian Komisi Hukum Nasional 2008 tentang "Tinjauan Terhadap UU No 5 Tahun 1960 tentang Peraturan Dasar PokokPokok Agraria", antara lain menemukan: Sangat mengherankan bahwa UUPA yang diakui sebagai suatu produk jaman Orde Baru yang cukup baik dalam keberpihakannya pada masyarakat adat, dalam prakteknya tidaklah demikian ${ }^{47}$.Yang mendasari UUPA sebagai lekatan ide pendirian negara RI, tetapi berfungsinya dipengaruh perjalanannya. Bahan hukumnya eks kolonial dan hukum adat. Akan banyak konvergensi capaian dari berbagai fungsi pemerintahan umumnya, ataumasih divergen untuk target utama, karena dalam tindak lanjutnya ia (hukum agraria ini) ditebar pada berbagai bidang. Jelas sangat perlu koordinasi, untuk menggolkan ideal-ideal politiknya dalam tata hukum atau realnya capaian positif dari ekspektasi atas keberadaan norma bersangkutan. Jazim Hamidi dan Malik, mengemukakan...Makna hakiki sebuah konstitusi bermukim teguh di dalam ide "Konstitusionalisme".... Maka dengan adanya suatu paham konstitusionalisme semua hak-hak warga negara akan terlindungi, dan hubungan antar lembaga Negara akan lebih mudah untuk mengadakan suatu koordinasi dalam melaksanakan tugasnya masing-masing, apalagi dalam masalah check and balance ${ }^{48}$.

2) Mengacu komentar R.M.Dworkin, bekenaan lahan pertanian sudah nyaris habis, panggilan tertuju padaotoritas mana yang harus sadar dapat segera bertindak. Anak petani secara masif tidak dapat untuk memperoleh pendidikan hingga setara dengan pemangku kehidupan yang affluent bisa memasukisemua struktur sosial dan kehidupan global, jika hanya mengandalkan sisa tanah. Pada perencanaan pembangunan jangka panjang yang lalu (pertama), satu kepala keluarga petani transmigrasi mempunyai 2 hektar, apakah itu sekedar percontohan, belakangan tenjadi kurang jelas. Di dalam case reliabilitas ketentuan UUPA, sikap struktur mesti tegas mengendalikan, bahkan menghukum kepemilikan melebihi jumlah yang pantas. Ketentuan sanksi pada UUPA sendiri terbilang lemah untuk dapat menetralisasi keadaan.

\footnotetext{
47 www.komisihukum.go.id//hukum agraria-1960-masyarakat-hukum-adat-perlukah-reformasi hukum agraria, Diakses, tgl 29 Mei 2015, pkl.15.20.

${ }^{48}$ Lihat, Jazim Hamidi dan Malik, Hukum Perbandingan Konstitusi (diedit Sunarni), Jakarta: Prestasi Pustaka, 2008, h.167-168.
}

\section{Isu Hukum: Apakah Mayoritas Petani Dapat Memeroleh Modal Dasar Lahan Pertanian, Baik Melalui Adat Maupun Hukum Negara?}

\section{a. Menimbang kepentingan pemilikan harta/ta- nah}

Ihering mengelompokkan kepentingan, atas: kepentingan individu, masyarakat, dan negara.Dari sana tampillah soal, minimum bagaimana energi yang dimiliki masing-masing agar hubungan dapat harmoni? Antinomi bervariasi seperti mana superior terhadap apa, atau dapatkah ko-eksis menurut hakikatmasingmasing. Hukum dalam negara dapat sempurna menurut pembenar yang dianut. Selain itu, ada common sensesebagai pedoman penataan untuk harmoni.

Bagaimana adat mengalokasi lahan faktor produksi bukanlah visi modernitas. Affirmasi terhadap rancangan pemisahan tanah kolektif, mungkin untuk sumber nafkah perorangan, dengan Peraturan Pemerintah. Tampaknya, sebagai faktor produksi yang diproyeksikan terhadap ketahanan energi nasional, alokasi ini agak statis, kurang responsif pada tantangan modern(ekonomi). Dengan mengutip L. Hager, B.F. Sihombing dalam disertasinya (pertanahan), mengemukakan:

Sementara itu hukum adat mencerminkan kultur tradisional dan aspirasi mayoritas rakyatnya. Hukum itu berakar dalam perekonomian subsistensi serta kebijakan paternalistik, kebijakan yang diarahkan pada pertalian kekeluargaan. Penilaian yang serupa dibuat dari hukum yang diterima di banyak negara-negara terbelakang. Hampir di manapun hukum ini telah gagal dalam melangkah dengan cita-cita modernisasi 49 .

Tiga aspek krusial dari uraian barusan, selaras dengan apa yang diperlukan ketentuan faktor produksi yaitu kultur dan penerimaan masyarakat,perekonomian subsistensi, danpengalamanless developed country tidak berhasil bersaranakan adat mengakomodasikan kemajuan. Cita kemerdekaan Indonesia adalah untuk mengejar kemajuan. Simpulnya, bahwa harus diandalkan rambu lainnya yang menunjang swatenaga ketentuan faktor produksi itu (dengan kekuasaan negara). Negara harus tetap hadir, akan tetapi terha-

\footnotetext{
${ }^{49}$ B.F.Sihombing, Evolusi Kebijakan Pertanahan Dalam Hukum Tanah Di Indonesia, pen.PT.Toko Gunung Agung,Tbk, 2005, h. 67 dengan mengutip L.Hager, The Rule of Lawyers in Developing Countries, dari buku Peranan Hukum Dalam Pembangunan Ekonomi, jilid I, h.180.
} 
dap perencanaan yang mantap (seperti tata ruang), pilihan hanya minta dukungan sosial luas, penataan region penampung kemajuan.

Mungkin tidak ada bangsa di dunia ini, memiliki hukum yang satu sistemyang sekali jadi meski melalui revolusi, sistem civil law menjalani proses yang panjang. Halnya dengan Indonesia dengan keindonesiaannya yang sungguh-sungguh masih tetap dalam proses menjadi. Yanis Maladi berbicara tentang Eksistensi Hukum Adat Dalam Konstitusi Negara Pasca Amandemen UUD 1945: "penegasan negara hukum Indonesia ... tidak harus dilihat sebagai suatu bangunan final, melainkan harus secara terus menerus dibangun untuk menjadi Indonesia yang sesungguhnya....makin menampilkan ciri khas keIndonesiaan yang membumi ke dalam habitat, tradisi, nilai-nilai kosmologi serta cita-cita modern Indonesia. Harus ada harmonisasi hukum adat dan hukum nasional dalam proses membangun negara hukum ala Indonesia ${ }^{50}$. Betul kesimpulan C. Saleh Adiwinata: ..., hendaknya jangan kita tafsirkan lembaga-lembaga dalam hukum adat menurut tafsiran hukum eropa dan demikian pula sebaliknya ${ }^{51}$. Namun dalam pilihan untuk maju harus melangkah dan progresif, membeli modernitas. Pembelian menu ini dibiayai oleh dukungan sosial luas pemangku adat yang harus melihat primasi dan prioritas sasaran kebijakan negara. Kepentingan umum mesti bersinggahsana pada kesadaran masyarakat adat, bahwa penikmat menu bersangkutan adalah generasi ke generasi. Itu sebabnya, kita membicarakan paket pemenuhan hal subsistensi dan ketahanan sesuatu.

\section{b. Kepastian Hak Mendapat Faktor Produksi Pertanian}

Tujuan seperti kepastian tampak sebagai prinsip. Dalam pertimbangan UUPA, bahwa hukum barat tidak memberi kepastian bagi anggota masyarakat adat. Sebaliknya, yang terbiasa dengan 'rasionalitas peradaban civil law', bahwa bertransaksi serah terima dalam hukum adat, kurang terdapat kepastian terutama penegakan (enforceability). Oleh karena, subjek yang full power sebagai individu tidak ada di

\footnotetext{
${ }^{50}$ Yanis Maladi, Eksistensi Hukum Adat Dalam Konstitusi Negara Pasca Amandemen UUD 1945, dalam Jurnal Hukum dan Pembangunan Tahun ke 41 No.3 Juli 2011,Jakarta: Badan Penerbit FH UI, h.432-433.

${ }^{51}$ C. Saleh Adiwinata, Pengertian Hukum Adat Menurut UndangUndang Pokok Agraria, Bandung: Alumni, 1983, h.65.
}

dalamnya, akibatnya civil law telah bertumbuh jadi hukum yang hidup. Sudah langka kita yang cukup luwes memadukan 'tanpa diatur lebih dahulu ada hukuman', 'tak dipisah publik dan privat' ${ }^{52}$. Kelsen melihat keadilan sebagai pertimbangan nilai yang bersifat subjektif. Ia mengatakan: Jadi, tidak mungkin pula adanya suatu tatanan yang adil meskipun atas dasar anggapan bahwa tatanan ini berusaha menciptakan bukan kebahagiaan setiap orang perorangan, melainkan kebahagiaan sebesar-besarnya bagi sebanyak mungkin individu yakni pembuat hukum, dianggap sebagai kebutuhan-kebutuhan yang patut dipenuhi, seperti kebutuhan pangan, sandang, dan papan $^{53}$. Pada Energi Nasional yang disambungkan pada peran perorangan dalam jumlah sebesar besarnya. Perlunya perbuatan lebih adil, didorong Pasal 2 Ayat (1), (2), dan (3) UUPA: negara berkuasa penuh untuk menata. Negara menguasai, menentukan penggunaan. Memajukan desa misalnya, desa yang harus menyesuai pada perencanaan yang lebih besar, jika tidak, akan tersisihkan oleh persaingan.

\section{c. Negara Dapat Merasionalkan distribusi lahan faktor produksi}

Dalam buku Genesis 15,7-9 "The Lord said to Abram, I brought you here from Ur in Caldea, and I gave you this land". Abram asked, "Lord God, how can I know the land will be mine?". Then the Lord told him, "Bring me a three-year-old cow, and a young pigeon”. Abraham mentaati semua hal yang diperintahkan Almighty God (Tuhan Yang Maha Esa). Ketimbang membayangkan hakim mewakili Tuhan, saya merasa afdal menyebut Negara mewakili Tuhan. Dengan Hak Menguasai atas tanah, Negara menentukan kemakmuran bagi semua.

Yang berdasar atas hukum adat, mengindahkan unsur yang bersandar pada hukum agama, menuju pada bagaimana agama memandang tanah sebagai faktor produksi. Alford T.Welch, tentang agama yang hidup: Traditional Muslims view virtually all aspects of individual and group life as being regulated or guided by Islam, which is seen as a complete, complex religious and social system. in which individuals,

\footnotetext{
${ }^{52}$ Soepomo, Bab-Bab Tentang Hukum Adat, Jakarta: PT Pradnya Paramita, cet.ketujuhbelas (tanpa tahun),h.24.

${ }^{53}$ Hans Kelsen, Teori Umum Tentang Hukum Dan Negara (diterjemahkan oleh Raisul Muttaqien dari Hans Kelsen, General Theory of Law and State, New York: Russel and Russel, 1971), Bandung: Nusamedia dan Nuansa, 2006, h.7.
} 
societies and governments should all reflect the will of God $^{54}$. Agama-agama besar lainnya, memandang Tuhan berkehendak membuat manusia bahagia. Fungsi bumi, sesuai kepentingan rakyat, permintaan zaman soal agraria. Bertitik tolak dari 'untuk maslahat umum', wajarlah warga negara bermimpi (vision) seperti apa kesejahteraan/kemakmuran bersama itu. Tugas legislasi dan eksekusi perlu dimonitor untuk mengepas berapa tatanan diserasikan memastikan sasaran terjamin terwujud'. Jika lahan sudah pada segelintir pihak, Negara tidak bersalah, mengambil alih dengan kompensasi kemudian diredistribusi pada unsurnya. Dengan cara itu, yang mau dan berbakat petani dapat responsif memenuhi peran (bagi diri/keluarga dan membangun energi nasional), serta merta harus lebih merasionalkan cara/teknik bertani mengingat aturan membuka diri (adaftif) terhadap perkembangan zaman pada segala lapangan keagrariaan. Penggagasan keunggulan pertanian akan diterima dan dipasarkan ditunjang pengaturan yang kondusif.

\section{Kesimpulan}

1. Reliabilitas ketentuan faktor produksi pertanian dalam UUPA yang berjiwakan Pancasila dan UUD Negara Republik Indonesia Tahun 1945 sesungguhnya merupakan janji negara, berpotensi diwujudkan secara optimum dengan sinergitas pengaturan lanjutan dan eksekusi antar segmensegmen bidang pemerintahan yang dapat mendistribusikan lahan-lahan pertanian secara tepat pada warga negara. Adanya bagian mendasar pengaturan keagrarian yang fungsional perlu ditata ulang, disesuaikan dengan kebutuhan hukum masyarakat dan perkembangan zaman, dan hubungan internasional terkait dengan proses kemajuan kehidupan berbangsa dan berkonstitusi,tidak menghalangi realisasi potensi tersebut. Proyeksi pemberian kesempatan petani berperan lebih akan menjamin kelangsungan kejayaan bangsa dan negara. Berdasar capaian realisasi janji UUPA yang belum menggembirakan dari cara konvensional, tak perlu membuat pesimis karena gawe (work) bersama ini bagian dari pematangan demokrasi dan bernegara hukum yang terus diperjuangkan.

2. Dengan rencana yang solid, layak direalisasikan mayoritas petani memeroleh modal dasar lahan

\footnotetext{
${ }^{54}$ Alford T.Welch, Handbook of Living Religions, Penguin books, 1997 (yang diedit John R.Hinnells), h.162.
}

pertanian disesuaikan dengan tuntutan perkembangan cara-cara pertanian kontemporer (tanpa terikat kuantifikasi luasan), diarahkan yang lebih produktif bagi masyarakat luas sesuai potensi khas daerah, dan penerimaan pasar. Kebijakan yang dinamis mengantisipasi pilihan teknologi bidang pemenuhan kebutuhan hidup dan kebutuhan ketahanan energi nasional menunjang pelindungan proses berproduksi dan distribusi komponen produk yang diunggulkan. Sumber pengadaan lahan adat dipelihara untuk kolektivitas menurut karakteristik budaya yang perlu dipelihara. Cara perkoperasian yang dapat menyambung rasa solidaritas antar petani berkesadaran luas dan luwes harus digalakkan.

\section{Saran}

1. Merealisasikan janji ketentuan faktor produksi pertanian dikelola secara wajar dan terencana dengan baik seiring sistem penyelenggaraan pemerintahan, dan melindungi adat sebagai bagian budaya bangsa. Sehubungan dengan hal tersebut, aturan tindak lanjut berupa undang-undang maupun peraturan pemerintah dan ke bawahnya semestinya tidak mendeviasikan ketentuan terkait jaminan faktor produksi pertanian, melainkan diupayakan terpadu sebagai realisasi melalui kewenangan masing-masing pada legislasi dan kebijakan eksekutif.

2. Pemerintah dan pemerintah daerah perlu meningkatkan efektivitas kebijakan terpadu dalam regulasi dan eksekusi pemanfaatan lahan faktor produksi pertanian untuk pemenuhan kebutuhan dasar dan peningkatan taraf hidup terintegrasi dengan kerangka pembentukan ketahanan energi nasional. Penyelarasan tindaklanjut ketentuan faktor produksi dengan asas aturannya yang melindungi rakyat (janji negara) mesti dari waktu ke waktu diupayakan. Distribusi lahan oleh pemerintah daerah ditekankan pada kualitatif, tidak mesti terikat luasan disesuaikan dengan potensi optimalisasi yang ditunjang teknologi tepat guna menciptakan keunggulan dengan tetap memelihara keberlangsungan lingkungan sehat dan lestari. Petani diarahkan agar dapat mengadopsi perkembangan teknologi yang tepat guna, difasilitasi dengan sarana prasarana guna menghasilkan kebutuhan pokok dan keunggulan berdasarkan karakteristik potensi lokal. Lahan dari masyara- 
kat adat diarahkan pemanfaatannya menunjang pelestarian budaya komunitas bersangkutan, tanpa mengurangi kontribusi menunjang penataan pemanfaatan tanah sebagai sumber penghidupan kekuatan lokal dan energi nasional.

\section{Daftar Pustaka}

\section{Buku}

Alford T.Welch, Handbook of Living Religions (diedit John R.Hinnells), Penguin Books, 1997.

Bachtiar Effendi, Kumpulan Tulisan tentang Hukum Tanah, Bandung: Alumni, 1982.

Barry Knight, et al, Reviving Democracy - Citizen at the Heart of Governance, London: Earthscan Publication Limited, 2002.

B.F.Sihombing, Evolusi Kebijakan Pertanahan Dalam Hukum Tanah Di Indonesia, Jakarta: PT.Toko Gunung Agung,Tbk, 2005.

Biro Hukum Dan Hubungan Masyarakat Badan Pertanahan Nasional, PENGADAAN TANAH Bagi Pembangunan Untuk Kepentingan Umum, Jakarta: Yayasan Bhumi Bhakti Adhiguna, 1994.

Buchari Bachter, MT Ketua Umum BPD HIPMI Sumatera Barat, Rancangan RPJMN 2015 - 2019 Dilihat Dari Sisi Dunia Usaha Dalam Menghadapi Komunitas Ekonomi ASEAN 2015.

C. Saleh Adiwinata, Pengertian Hukum Adat Menurut Undang-Undang Pokok Agraria, Bandung: Alumni, 1983.

Eryan A Garner (editor in chief), Black's Law Dictionary, eight edition, 2009.

Franz Magnis Suseno, Filsafat Kebudayaan,(diedit Swandi S. Brata), Jakarta: PT Gramedia Pustaka Utama 1992.

Frederich Julius Stahl, dikutip dalam Krisna Harahap, Konstitusi Republik Indonesia-Sejak Proklamasi hingga Reformasi, Bandung: Gafitri Budi Utami, 2004.

George Whitecross Paton, A Text Book of Jurisprudence, Oxford at Clarendon Press, 1946.

Hans Kelsen, Teori Umum Tentang Hukum Dan Negara (diterjemahkan oleh Raisul Muttaqien dari Hans Kelsen, General Theory of Law and
State, New York: Russel and Russel, 1971), Bandung: Nusamedia dan Nuansa, 2006.

Jazim Hamidi dan Malik, Hukum Perbandingan Konstitusi (diedit Sunarni), Jakarta: Prestasi Pustaka, 2008.

J.M.Juran, Juran on Quality by Design - The New Steps for Planning Quality into Goods and Services, The Free Press a Division of Simon \& Schuster Inc. 1230 Avenue of Americas, 1992.

Johnny Ibrahim, Teori Dan Metode Penelitian Hukum Normatif, Malang: Bayumedia Publishing, 2005.

Kinayati Djoyosuroto, Filsafat Bahasa, Yogyakarta: Pustaka Book Publisher, cet.kedua (edisi revisi), 2007.

Krisna Harahap, Konstitusi Republik Indonesia-Sejak Proklamasi hingga Reformasi, Bandung: Grafitri Budi Utami, 2004.

Majelis Permusyawaratan Rakyat, Panduan Pemasyarakatan Undang-Undang Dasar Negara Republik Indonesia Tahun 1945 Sesuaidengan Urutan Bab, Pasal, dan Ayat, Sekretariat Jenderal MPR RI: 2008.

Maxime Kleinpeter, Energy Planning And Policy, Unesco, 1995.

Notonagoro, Politik Hukum Dan Pembangunan Agraria Di Indonesia, Jakarta: PT.Bina Aksara, 1984.

Pusat Bahasa Departemen Pendidikan Nasional, $\mathrm{Ka}$ mus Besar Bahasa Indonesia, edisi keempat, Jakarta: PT Gramedia Pustaka Utama, 2008.

Paul A. Samuelson dan William D. Nordhaus, (edisi terjemahan), Ilmu Mikro Ekonomi, Jakarta: P.T. Media Global Edukasi, 2003.

R.M.Dworkin, The Philosophy of Law, Oxford University Press, 1977.

R.Subekti dan R.Tjitrosudibio, Kitab Undang-Undang Hukum Perdata, Jakarta: Pradnya Paramita, 1978;

R.Subekti, Hukum Adat Indonesia Dalam Yurisprudensi Mahkamah Agung, Bandung: PT.Alumni, cetakan kelima, 2006.

Soerjono Soekanto dan Mamudji, Penelitian Hukum Normatif Suatu Tinjauan Singkat, Jakarta: PT Raja Grafindo Persada, 1983.

Soepomo, Bab-Bab Tentang Hukum Adat, Jakarta: PT Pradnya Paramita, cet.ketujuh belas (tanpa tahun). 
Sudargo Gautama, Indonesian Business Law, Bandung: PT.Citra Aditya Bakti, 1995.

Sudikno Mertokusuma, Mengenal Hukum, Yogyakarta: Liberty, 1985.

W.Friedmann, Legal Theory, Columbia University Press New York: stevens \& Son Limited, edisi pertama, 1967.

www.komisihukum.go.id/index.php? option=com_ content \&view=article \&id=170: hukum agraria-1960-masyarakat-hukum-adat-perlukahreformasi hukum agraria, Diakses, tgl 29 mei 2015, pkl.15.20.

Yanis Maladi, Eksistensi Hukum Adat Dalam Konstitusi Negara Pasca Amandemen UUD 1945, dalam Jurnal Hukum dan Pembangunan Tahun ke 41 No.3 Juli 2011, Jakarta: Badan Penerbit FH UI.

\section{Peraturan Perundang-undangan}

Undang-Undang No.5 Tahun 1960 Tentang Peraturan Dasar Pokok-Pokok Agraria

Undang-undang Nmor 32 tahun 2009 Tentang Perlin- dungan dan Pengelolaan Lingkungan Hidup.

Undang-Undang Nomor 41 Tahun 2009 Tentang Per- tambangan Mineral dan Batubara

\section{Siaran Televisi:}

KOMPAS TV, pkl.20.50 tanggal 17 Mei 2015.

TV RI, siaran tanggal 26 Mei 2015 Pukul 13

15. 